\title{
Dvacet pět let systematického sledování jakosti podzemních vod v České republice
}

\section{VÍT KODEŠ, MIROSLAVA SVÁTKOVÁ, JINDŘICH FREISLEBEN}

\author{
Klíčová slova: podzemní voda - jakost vod - monitoring
}

\section{SOUHRN}

Sledováním jakosti podzemních vod se v České republice věnuje mnoho subjektů s různými cíly sledování a s různou kvalitou získávaných výsledků. Český hydrometeorologický ústav dlouhodobě buduje a rozvíjí jednotný systém monitoringu poskytující srovnatelná data napříč územím republiky. Historie tohoto monitoringu jakosti podzemních vod v ČHMÚ sahá až do konce 50. let minulého století, systematický monitoring se datuje od začátku 90. let minulého století. Za posledních 25 let tohoto sledování se díky investicím do monitorovací sítě, rozvoji analytických metod a rostoucím požadavkům ČHMÚ na kvalitu vzorkovacích a analytických prací výrazně zlepšila vypovídací schopnost a kvalita pořizovaných dat. Príspěvek shrnuje historický vývoj monitoringu jakosti podzemních vod zabezpeČovaného ČHMÚ a jeho prínos pro stav poznání jakosti podzemních vod v ČR.

\section{ÚVOD}

Podzemní vodaje významným zdrojem pitné vody vČeské republice. Monitoring tohoto zdroje je na území ČR realizován mnoha subjekty vždy s ohledem na charakter zjištovaných informací a relevantní legislativu. Vzhledem k vysokému počtu subjektů pořizujícím údaje o jakosti podzemních vod se i kvalita získaných údajů může lišit v závislosti na kvalitě vzorkařských prací a kvalitě analytických laboratoří. Vysoký počet subjektů také zcela jistě nepřispívá k plné porovnatelnosti výsledků laboratorních analýz. Z tohoto pohledu se Český hydrometeorologický ústav (ČHMú), jako organizace zajištujující monitoring jakosti podzemních vod v celostátním měřítku, snaží dlouhodobě zabezpečit kvalitní data jakosti podzemních vod České republiky.

\section{METODIKA}

Objekty státní sítě sledování jakosti podzemních vod tvoří podmnožinu z cca 1850 objektů pozorovací sítě podzemních vod ČHMú. Sít byla koncipována tak, aby sledovala pokud možno neovlivněný režim podzemních vod a záměrně se vyhýbala lokalitám antropogenně ovlivněným bodovými zdroji znečištění. Ve strukturách české kř́dové pánve jsou objekty lokalizovány tak, aby pokrývaly oblasti infiltrace, transportu a odvodnění dané struktury. Každý útvar podzemních vod je, pokud je to možné, monitorován nejméně jedním monitorovacím objektem. Optimální počet monitorovacích objektů je tři a více na útvar podzemních vod v závislosti na hydrogeologických podmínkách a velikosti plochy útvaru. Hloubková stratifikace monitorovacích míst je v dostatečné míre zohledněna $v$ samostatných místech, tj. pozorování různých kolektorů je ve stejném místě zajištěno více samostatnými monitorovacími objekty.
Sit pro sledování jakosti podzemních vod byla zpočátku (60.-70. léta) tvořena pouze prameny, $v 80$. letech byly do sítě začleněny mělké vrty $\vee$ kvartérních sedimentech a na počátku 90 . let byly do sítě zařazeny i vrty sledující hluboké hydrogeologické struktury. Dalším výrazným rozšířením prošla sít na konci prvního desetiletí tohoto století a naposledy byla rozšírena v tomto roce. Jelikož ČHMú nedisponuje vlastními vzorkařskými a analytickými kapacitami, jsou veškeré vzorkařské a analytické práce zabezpečovány externími dodavateli, vybíranými ve veřejných soutěžích v souladu se zákonem č. 137/2006 [1]. Zde je nutno podotknout, že výběr dodavatelů byl již od 1. poloviny 90 . let, tedy daleko před přijetím výše zmíněného zákona, realizován formou výběrových řízení, což je na podmínky tehdy panující v ČR jistě výjimečné. Díky tomu se kvalita prací na monitoringu ČHMú kontinuálně zlepšovala, až dosáhla stávající špičkové úrovně. Z logistických důvodů bylo území ČR na počátku 90. let rozděleno do sedmi vzorkovacích oblastí (západní Čechy, jižní Čechy, střední Čechy, severní Čechy, východní Čechy, jižní Morava a severní Morava), tyto vzorkovací oblasti jsou využívány dodnes při výběrových řizeních a na každou z těchto oblastí je podepisována separátní smlouva o dílo.

Vzorkování podzemních vod je každoročně (až na výjimky v letech 2011 a 2013) prováděno $2 \times$ ročně $v$ cyklu jaro-podzim. Výběr sledovaných ukazatelů je a historicky byl dán prríslušnou platnou legislativou, dostupností analytických metod, pro identifikaci potencionálních polutantů podzemních vod se využívají i literární rešerše a výsledky monitoringu jakosti podzemních vod v ostatních státech. Členské státy EU měly za povinnost implementovat přislušné programy monitoringu (situační a provozní monitoring) v souladu s požadavky Rámcové směrnice o vodách [2], tyto programy byly v ČR spuštěny v roce 2007. Od počátku 21. století proběhlo i několik cílených screeningů širokého spektra polutantů z oblasti nebezpečných látek, a to jak v rámci výzkumných projektů $[3,4]$, tak $v$ rámci situačního monitoringu podle Rámcové směrnice o vodách. Na základě těchto screeningů se průběžně upravoval rozsah stanovovaných ukazatelů v následujících letech. Významným prvkem ovlivňujícím zásadním způsobem hodnověrnost výsledků jsou i požadavky na kvalitu prací ze strany ČHMÚ. V dnešní době jsou nadstandardní požadavky ČHMú v oblasti QA/QC zárukou vysoké kvality vzorkařských i analytických prací, a tím i vysoké kvality získávaných dat. Tato data jsou kontrolována a verifikována ve spolupráci s laboratořemi a poté uložena do národního informačního systému jakosti vod IS ARROW, provozovaného ČHMÚ. Tato data jsou následně dostupná veřejnosti na adrese http://hydro.chmi.cz/isarrow. 

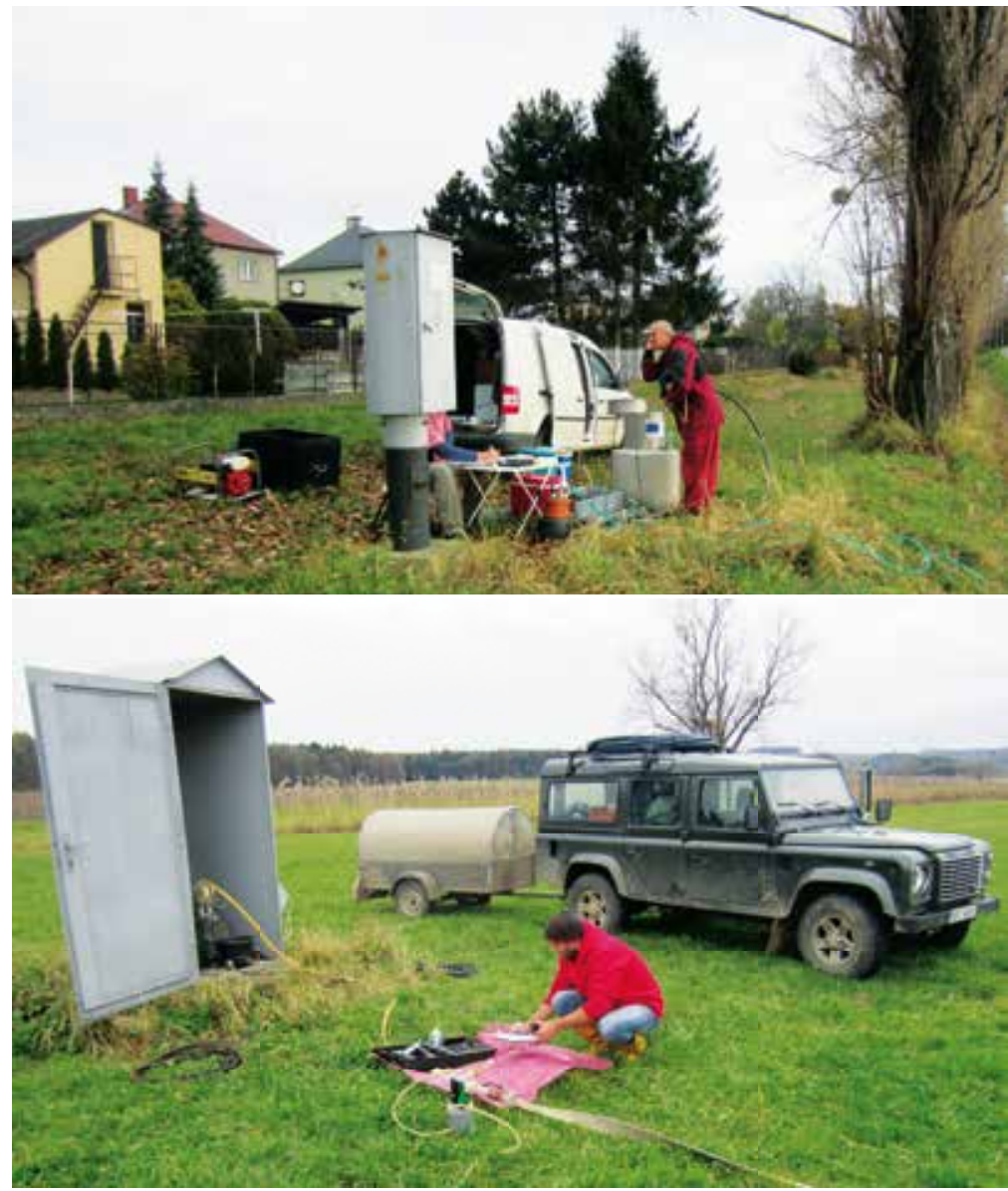

Obr. 1. Průběžné měření hodnot během čerpání před odběrem vzorku z vrtu

Fig. 1. Continuous recording of selected parameters during pumping before sampling of the well

\section{Systém zajištění kvality odběru vzorků a terénních měření}

Veškeré údaje, které jsou zaznamenávány při odběrech vzorků, je vzorkař povinen uložit za použití softwaru pro terénní měření a vytvoření protokolu o odběru vzorku poskytnutého ČHMÚ. Odběr vzorků podzemní vody z pramenů musí být prováděn podle ČSN EN ISO 5667-1 [5]. V okamžiku odběru vzorku zaznamená vzorkař mj. aktuální hodnoty pH, vodivosti, oxidačně redukčního potenciálu (Eh), rozpuštěného kyslíku, zákalu a teploty vody. Odběr vzorků podzemni vody z vrtů se musí provádět v dynamickém stavu (po čerpání, resp. u tlakových vrtů odpouštění, optimálně do ustálení následujících průběžně měřených parametrů: teplota vody, vodivost, pH a zákal). Vzorek vody je považován za ustálený, pakliže změna dvou po sobě jdoucích měření teploty, pH, vodivosti a zákalu je menší než $10 \%$. Pouze v ojedinělých případech je vzorek z vrtu odebírán zonálním vzorkovačem z předepsané hloubky. Při vzorkování vrtů je třeba zapustit čerpadlo do príslušné hloubky (od odměrného bodu, jímž je zpravidla okraj pažnice či okraj zhlaví vrtu) a po požadovanou dobu z ní zadaným množstvím čerpat/odpouštět podle požadavku ČHMú specifikovaného individuálně pro každý vrt. Odpouštění přetokových vrtů musí probíhat nejméně 2 hodiny, není-li stanoveno jinak, a to předepsanou vydatností. Před čerpáním/odpouštěním a při něm je povinností vzorkaře ve stanovených časech důsledně měřit a zapisovat požadované údaje ( $\mathrm{pH}$, vodivost, zákal, rozpuštěný kyslík, skutečně čerpanou vydatnost, teplotu vzduchu a vody, hladinu podzemní vody) včetně zápisu prípadných doprovodných jevů (pískování, barva vody, zákal atd.) či problémů s vrtem či čerpáním (obr. 1). Vzorkař zaznamenává též délku odpadu

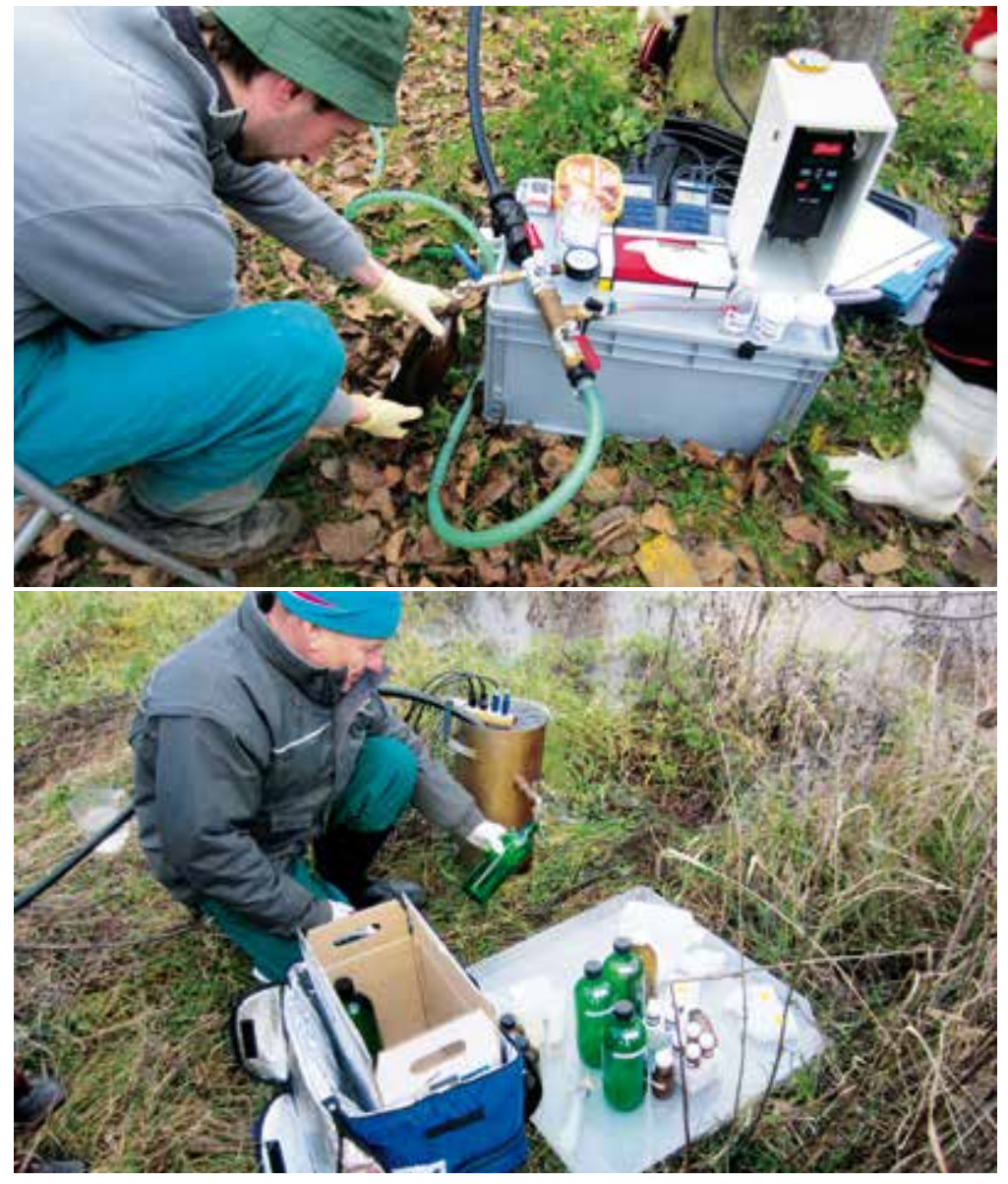

Obr. 2. Odběr vzorku (nahoře) s uložením vzorkovnic v chladicím boxu (dole)

Fig. 2. Groundwater sampling (above), storage of sampling bottles in a cooling box (below)

a jeho zaústění. Odčerpávaná voda zejména u objektů v kvartérních zvodních (mělké vrty do $20 \mathrm{~m}$ ) musí být vypouštěna $v$ dostatečné vzdálenosti (alespoň 10 m) tak, aby nedocházelo k ovlivnění vrtu vypouštěnou vodou. Po stanovené době rádným a pečlivým způsobem podle pokynů zpracovávající laboratoře a v souladu s ČSN EN ISO 5667-11 [6] odebere vzorkař laboratoří požadované množství neprovzdušněného vzorku a zaznamená aktuální hodnoty hladiny podzemní vody, pH, vodivosti, Eh, rozpuštěného kyslíku, teploty a zákalu vody v okamžiku odběru vzorku (obr. 2).

ČHMÚ požaduje použití ponorných odstředivých, popř. membránových čerpadel. Použití sacích čerpadel pro odběr vzorku je neprípustné. Preferuje se použití čerpadel s modulací průtoku. Pokud je požadován odběr vzorku vzorkovačem, musí vzorkař používat zonální vzorkovač. Pro průtoky pod $0,11 . \mathrm{s}^{-1} \mathrm{je}$ požadováno umístění ventilu pro vzorkovací okruh maximálně $2 \mathrm{~m}$ od vyústění hadice z objektu vrtu, aby nedocházelo ke změnám teplot při odběru. Dalším požadavkem je, aby zařizení pro odběr vzorku a potenciální zdroje znečištění (např. elektrocentrály, kanystry s pohonnými hmotami) byly uloženy odděleně, centrála uložena $v$ samostatném boxu a zabráněno kontaminaci čerpacích hadic a čerpadla během přepravy. Dále musí být zabráněno kontaktu hadic a ostatního vzorkovacího zařízení s okolním terénem např. použitím podložky (obr. 3). Nepřipouští se terénní měření v kádince. Požaduje se použití průtokových cel pro terénní měěení požadovaných parametrů (obr. 4). Prípustné intervaly odchylek měření v terénu vưči standardům jsou uvedeny v tabulce 1 . 

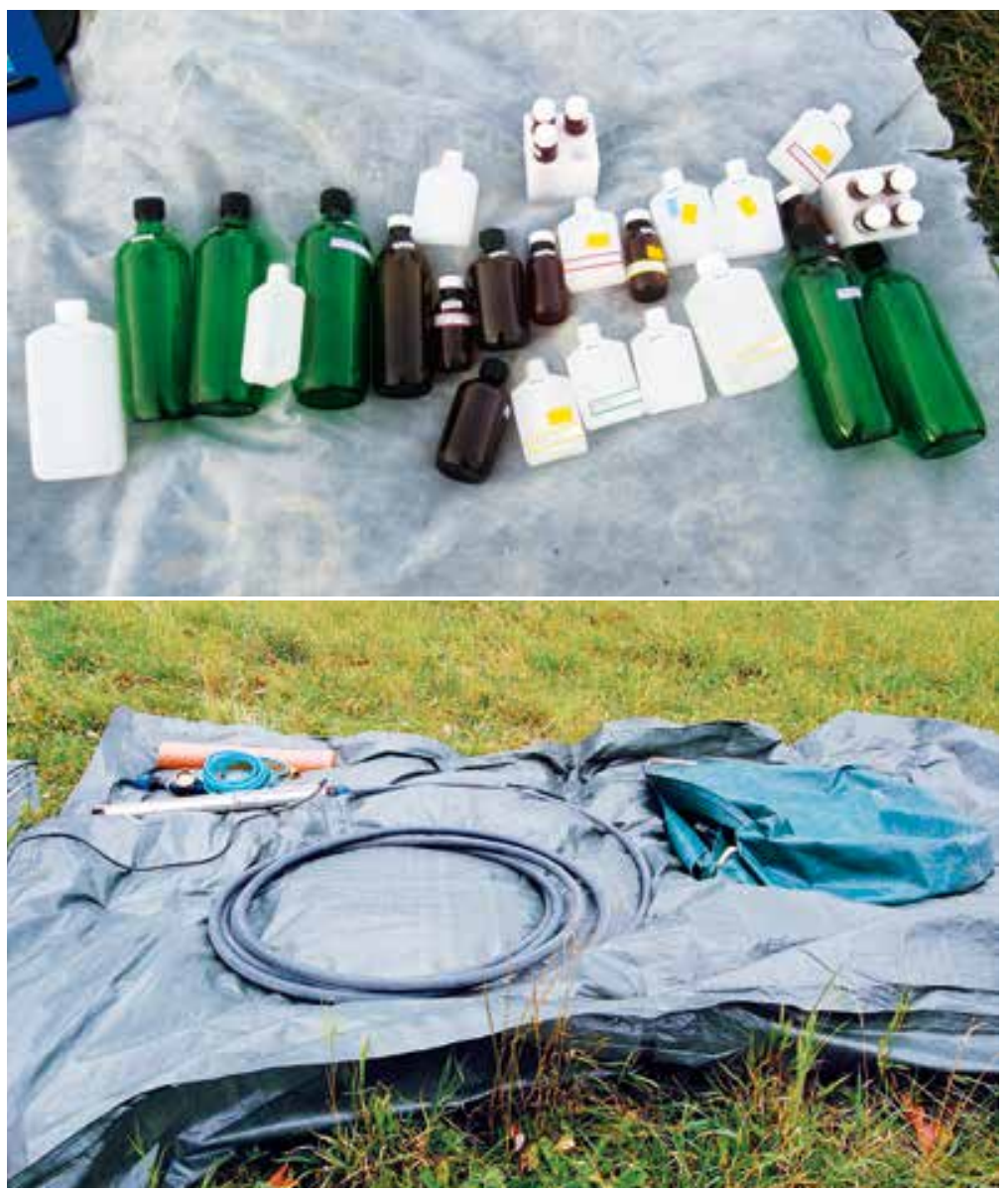

Obr. 3. Zamezení kontaminace vzorkovnic (nahoře) a vzorkovacího zařízení (dole)

Fig. 3. A contamination prevention of sampling bottles (above) and equipment (below)

Tabulka 1. Př́pustné odchylky měřenív terénu vưči kalibračním standardům

Table 1. Tolerable deviations from calibration standards for in situ measurements

\begin{tabular}{ll} 
Ukazatel & Odchylka \\
\hline $\mathrm{pH}$ v terénu & $+/-0,1$ \\
\hline oxidačně redukční potenciál v terénu & $+/-20 \mathrm{mV}$ \\
\hline měrná vodivost v terénu & $+/-5 \%$ \\
\hline
\end{tabular}

Laboratoře musí mít plnou odpovědnost za terénní přístroje a terénní měění, tj. provádění kalibrací a jejich navázání na metrologický systém laboratoře. Vzorkař musí vést doložitelné záznamy o kontrolách správnosti měěení a o kalibracích napríklad v prístrojových denících, které bude schopen dokladovat ČHMÚ. Denní kontrola správnosti měření používaných čidel je vyžadována. Konzervace vzorků musí být prováděna v souladu s ČSN EN ISO 5667-3 [7]. Laboratoř musí dodržovat požadavky normy, popř. musí mít laboratoř odchylné způsoby konzervace validovány v rámci akreditace podle ČSN EN ISO/IEC 17025 [8]. ČHMÚ požaduje nefixované vzorky uchovávat v prostředí o teplotě do $10^{\circ} \mathrm{C}$ až do zpracování v laboratoři. Požaduje se sledování teploty v chladicích boxech u každého vzorku v době od odběru do předání vzorku v analytické laboratoři, záznamy o průbězích teplot jsou po skončení vzorkování předávány ČHMú. Odběrové osádky musí používat chladicí boxy s aktivním chlazením nebo s namraženými chladicími vložkami (obr. 2).

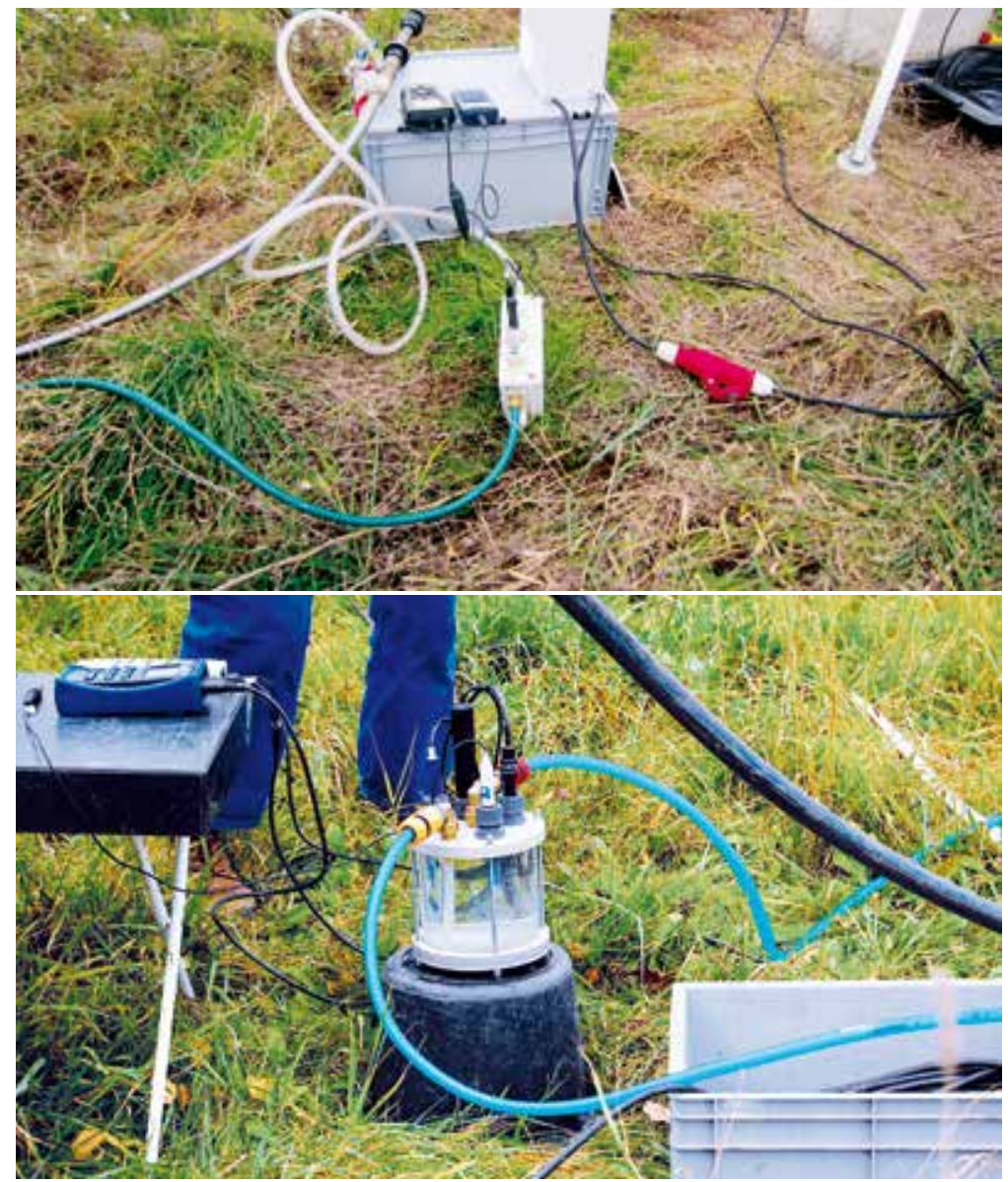

Obr. 4. Průtokové cely pro průběžné měření vybraných ukazatelů v terénu

Fig. 4. Flow-through cells for measurements of selected parameters in situ

\section{Systém zajištění kvality analytických prací}

Všechny ukazatele musí být analyzovány podle standardních operačních postupů akreditovaných podle normy ČSN EN ISO/IEC 17025 [8], laboratoř musí mít platnou akreditaci na všechna stanovení mimo hodnot stanovovaných výpočtem. Laboratoře se při provádění laboratorních měření řídí požadavky směrnice 2009/90/ES [9], které musí splňovat, a také se musí zúčastňovat všech mezilaboratorních srovnávacích zkoušek týkajících se analytů stanovovaných $\checkmark$ monitoringu ČHMÚ organizovaných subjekty oprávněnými pro tuto činnost v ČR. V prípadě nevyhovujících výsledků musí laboratoře neprodleně príijmout opatření k nápravě. Laboratoře jsou povinny výsledky autorizovat formou protokolu o zkoušce. Nedílnou součástí analytických výsledků je údaj o chybě stanovení.

ČHMÚ požaduje, aby byla všechna stanovení specifických organických látek (s výjimkou PAU) prováděna analytickými metodami, které poskytují informace o chemické struktuře analytu, tj. za použití hmotnostní spektrometrie. Laboratoř musí pro stanovení organických látek popsat způsob, jak zajištuje monitorování podmínek skladování vzorků a stability extraktů a kalibračních standardů v roztocích, včetně hodnot o stabilitě, kterou pořídila v rámci validace analytické metody. Laboratoř prokazuje způsob zajištění metrologické návaznosti specifikací kalibračních standardů s vhodnou expirací. Standardy musí být v prokazatelném vlastnictví laboratoře, která provádí analýzy. Pro každý kalibrační standard pro danou metodu laboratoř samostatně uvádí výrobce kalibračního standardu, číslo výrobní šarže a datum expirace. Pokud dojde v průběhu monitoringu pro ČHMÚ k ukončení expirace, laboratoř zakoupí včas nový 


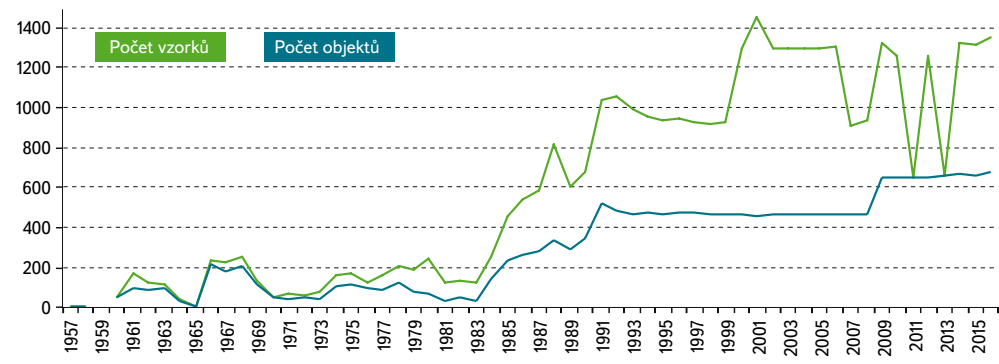

Obr. 5. Počet monitorovaných objektů a odebraných vzorků

Fig. 5. Number of monitoring sites and samples taken

standard tak, aby po celou dobu byly používány standardy před ukončením expirační lhůty. Laboratoř dokladuje systém rízení jakosti QC (typy a počet kontrolních vzorků) pro všechny analyzované parametry s tím, že ČHMÚ má následující minimální požadavky na analýzu kontrolních vzorků: laboratorní duplikát ( 5 \% vzorků, minimálně každý den měření), slepý pokus (5\% vzorků, minimálně každý den měřní) a fortifikovaný slepý pokus nebo fortifikovaná matrice (5\% vzorků). Laboratoř predává po skončení jednotlivých vzorkovacích období
ČHMÚ stručnou písemnou zprávu o průběhu a výsledcích těchto interních kontrol kvality práce. Tato zpráva musí obsahovat alespoň termíny těchto kontrol, specifikaci konkrétních vzorků a výsledek této kontroly.

\section{Vývoj monitorovací sítě}

Počátek sledování jakosti podzemních vod v ČHMÚ se datuje k roku 1957, kdy byly ovzorkovány první čtyří objekty. Od 60. let až do roku 1983 se vzorkovaly prevážně prameny, a to $v$ nepravidelném intervalu $1 \times$ za několik let. $\checkmark$ roce 1984 začalo pravidelné vzorkování mělkých vrtů současně s prameny $2 \times$ ročně. Na přelomu 90 . let byly do sítě ČHMÚ zařazeny vrty sledující hluboké vodohospodářsky významné struktury (hlavně křídové a terciérní pánve). $\vee$ tomto období se počet vzorkovaných objektů ustálil na přibližně 460 . V roce 2009 došlo, v rámci rekonstrukce sítě ČHMÚ financované z Fondu soudržnosti EU, k zařazení nově vybudovaných vrtů a k navýšení počtu monitorovacích míst na 613. Současně bylo do programu sledování jakosti podzemních vod navíc zařazeno, po dohodě s jejich provozovateli, 39 významných zdrojů zásobování obyvatelstva pitnou vodou s vydatností větší než 50 l.s.-1.V roce 2016 budou
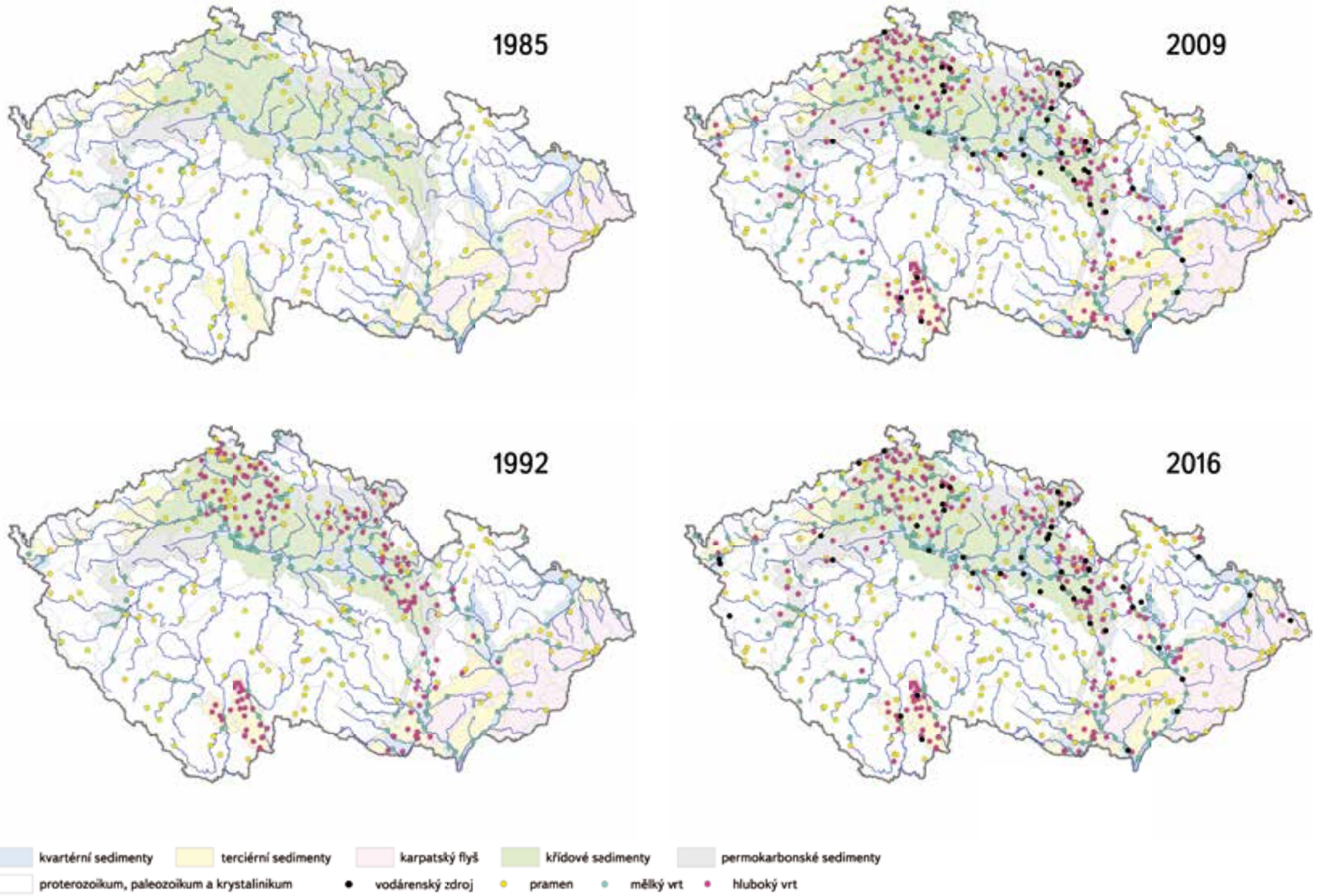

Obr. 6. Rozložení monitorovací sítě v letech 1985, 1992, 2009 a 2016

Fig. 6. Monitoring network layout in 1985, 1992, 2009 and 2016 
zahrnuty další objekty včetně menších zdrojů zásobování obyvatelstva pitnou vodou tak, aby monitoring ČHMÚ pokrýval 173 ze 174 útvarů podzemních vod vymezených vyhláškou 5/2011 [10] pro účely sledování podle Rámcové směrnice o vodách [2]. Pouze v jednom malém útvaru podzemních vod o rozloze $43 \mathrm{~km}^{2}$ (Krystalinikum v povodí Svratky-Svitava po soutok s tokem Punkva, ID 65602) nebyl dosud nalezen žádný objekt vhodný pro vzorkování podzemních vod. Počet sledovaných objektů se z původních 481 v roce 1992 zvedl na 675 v roce 2016 (obr. 5). Většina objektů v síti je v dobrém technickém stavu, existují ovšem objekty, které byly prozatím v síti ponechány i přes špatný technický stav s ohledem na zachování kontinuity časových řad, jelikož chybí finanční prostředky na opravu nebo náhradu objektů, a v daném vodním útvaru neexistuje monitorovací objekt, který by mohl stávající nahradit. Hustota a rozložení monitorovací sítě se významně změnily zejména v letech 1985, 1992 a 2009 (obr. 6).

\section{Sledované ukazatele}

Rozsah sledovaných ukazatelů (obr. 7) se v průběhu času zvyšoval tak, jak se vyvíjela analytická technika a jak se měnila legislativa platná pro oblast jakosti podzemních vod. Až do roku 2011 neexistovala v ČR závazná legislativa pro hodnocení jakosti podzemních vod, jediným použitelným legislativním predpisem byla vyhláška č. 252/2004 [11] a předcházející předpisy platné pro pitnou vodu. Implementací směrnice 2006/118/ES [12] do legislativy ČR vyhláškou č. 5/2011 [10] byl tento nedostatek v roce 2011 napraven. V roce 2002 proběhl první screening nebezpečných látek [13], na jehož základě byl v roce 2005 rozšířen rozsah stanovovaných ukazatelů, zejména pesticidů. V roce 2007 byl monitoring poprvé realizován v souladu s požadavky Rámcové směrnice o vodách, a to programem situačního monitoringu, kdy byl logicky stanovován širší rozsah ukazatelů než v predchozích letech. K dalšímu významnému rozšírení sledovaných látek (opět zejména pesticidů a jejich metabolitů $v$ rámci screeningu) došlo v roce
2009 a poté v roce 2013 (pesticidy a jejich metabolity, prioritní látky v rámci situačního monitoringu). Sledování pesticidů, jejich metabolitů i prioritních látek v podzemních vodách $v$ tak širokém rozsahu zajištuje $\vee$ ČR pouze ČHMÚ. Na druhou stranu monitoring ČHMÚ nezahrnuje a ani nikdy nezahrnoval sledování mikrobiálního znečištění podzemních vod.

\section{VÝSLEDKY A DISKUSE}

Za celou dobu pozorování bylo do informačního systému ČHMÚ uloženo 3589619 hodnot z celkem 34758 vzorkü, za posledních 25 let od roku 1991 bylo uloženo 3315859 hodnot (92 \% veškerých hodnot) z 27617 vzorků (79 \% všech vzorků). V posledních letech každoročně do databáze přibývá zhruba 250000 až 350000 hodnot v závislosti na rozsahu sledovaných ukazatelů. Nejproblematičtější z celého spektra v současnosti sledovaných látek z hlediska překročení limitů pro podzemní vody jsou dusíkaté látky [14] (obr. 8) a metabolity pesticidů [14, 15] (obr. 9).

Za posledních 25 let se monitoring jakosti podzemních vod vzhledem k vývoji dostupných analytických metod a nekompromisním požadavkům ČHMÚ na kvalitu vzorkovacích a analytických prací posunul na úroveň zcela srovnatelnou s nejvyspělejšími státy. Náklady obecně odpovídají nárůstu počtu monitorovacích objektů a sledovaných ukazatelů a reflektují i počet odebraných vzorků a typ programu monitoringu v daném roce (obr. 10). Náklady na monitoring samozřejmě vzrostly, ale při zohlednění změny cenových hladin v ČR a kupní síly během posledních 25 let k žádnému dramatickému nárůstu nákladů překvapivě nedošlo. Dá se říci, že dnešní nastavení monitoringu je velmi efektivní, jako indikátor Ize použít náklady na získání jedné hodnoty, kdy se náklady na jeden výsledek (číslo, koncentraci) postupně snižovaly z cca 90 Kč $\checkmark$ roce 1993 na 50 Kč v roce 2015 (obr. 11).

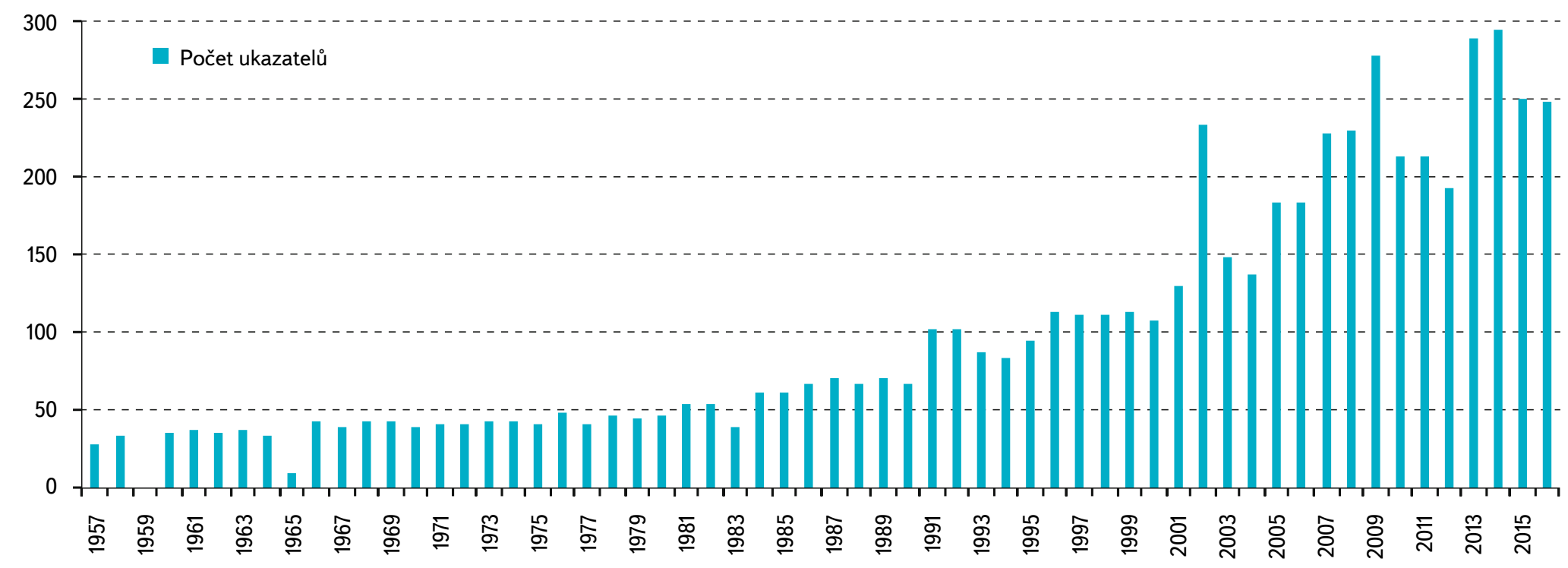

Obr. 7. Počet sledovaných ukazatelů

Fig. 7. Number of monitored determinants 


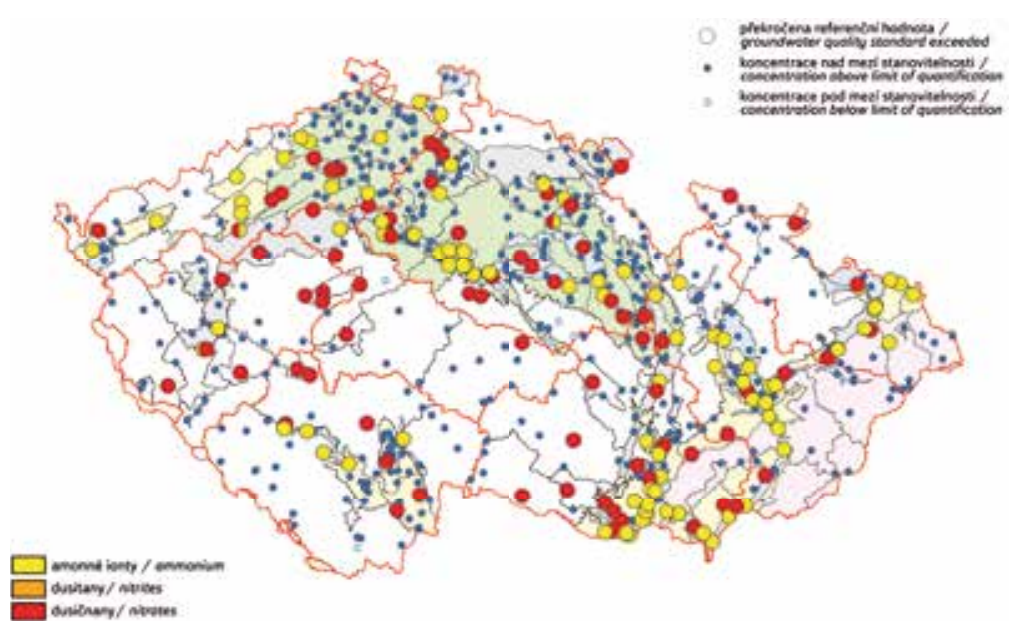

Obr. 8. Překročení limitů pro dusíkaté látky v roce 2014 [14]

Fig. 8. Groundwater standard exceedance for nitrogen compounds in 2014 [14]

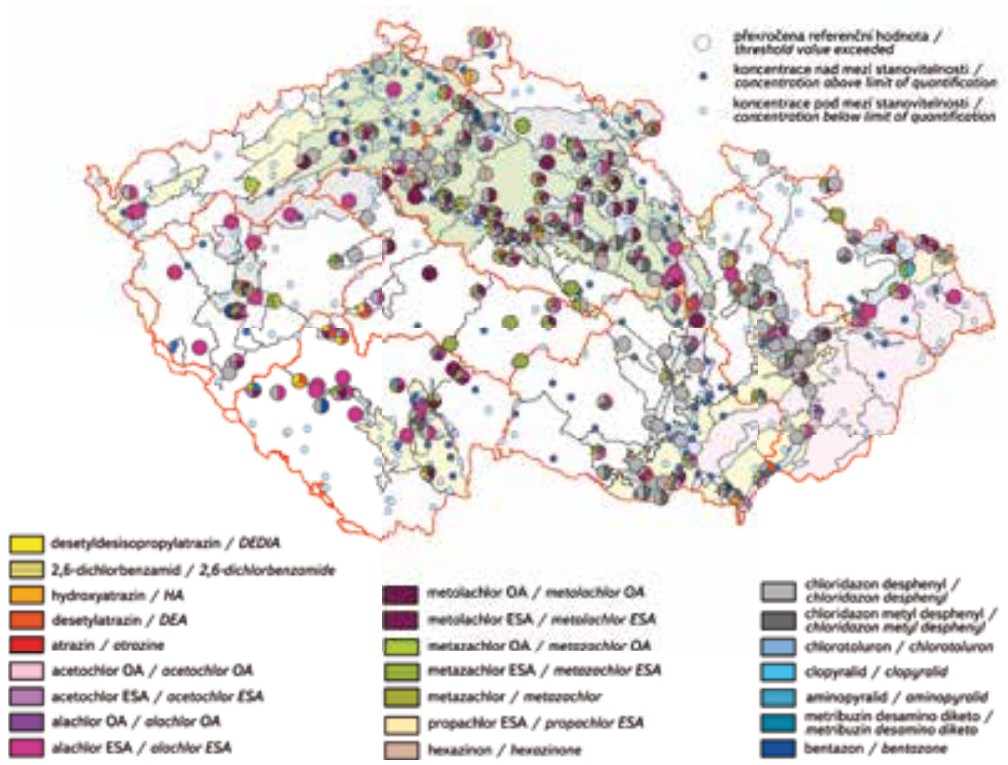

Obr. 9. Překročení limitu pro pesticidy v roce 2014 [14]

Fig. 9. Groundwater standard exceedance for pesticides in 2014 [14]

\section{ZÁVĚR}

Výsledky monitoringu jsou dnes využívány nejen pro účely sestavování vodní bilance, hodnocení stavu vod, hodnocení stavu vodních útvarů a plánování v oblasti vod podle zákona č. 254/2011 [16], ale i v rámci jiných aktivit vyplývajících z ostatních závazků ČR, jako je např́klad reporting pro Evropskou agenturu pro životní prostředí (EEA) v rámci sítě EIONET [17], implementace směrnice 91/676/EHS [18] a vymezení zranitelných oblastí podle této směrnice, implementace směrnice 2009/128/ES [19] prostřednictvím Národního akčního plánu ke snižení používání pesticidů v České republice [20] a ve spolupráci s Ústředním kontrolním a zkušebním ústavem zemědělským i jako nástroj pro regulaci a povolování prostředků na ochranu rostlin na území ČR. Z dosavadních zkušeností se ukazuje, že největší komplikací pro zdárnou realizaci tohoto monitoringu je chybějící systém dlouhodobého financování. Tento celostátní monitoring by měl zcela logicky patřit mezi strategické a dlouhodobé aktivity České republiky. Způsob zajištění jeho financování tomu ale zdaleka neodpovídá. Přesto se daři tento monitoring realizovat, ba co více, zvyšovat jeho kvalitu, na kterou může být Česká republika oprávněně hrdá.

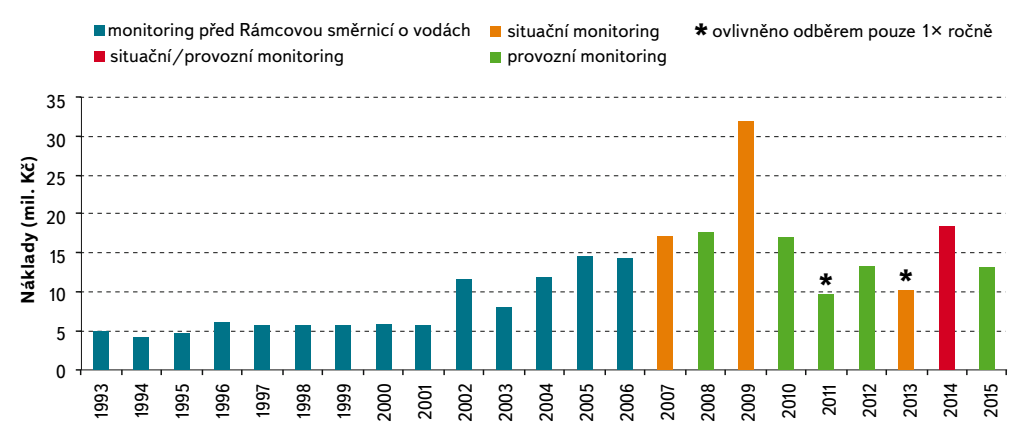

Obr. 10. Náklady na monitoring

Fig. 10. Cost of the monitoring

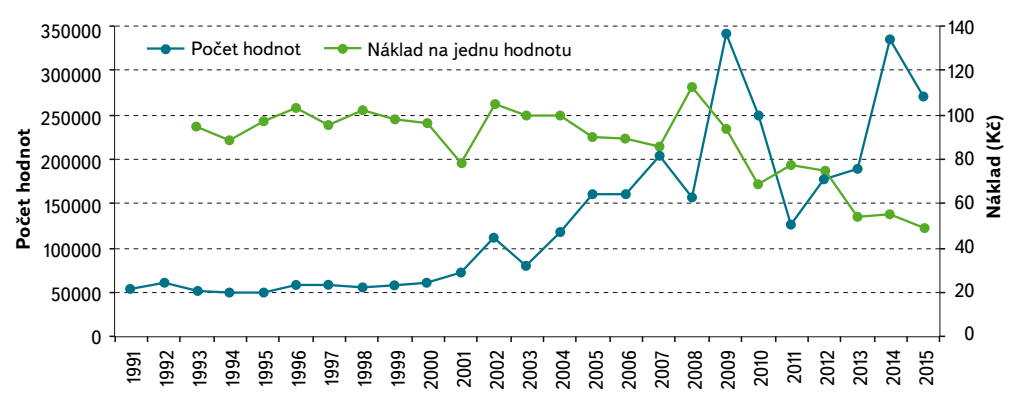

Obr. 11. Počet naměřených hodnot a indikátor efektivity monitoringu (náklad na pořizení 1 koncentrační hodnoty)

Fig. 11. Number of acquired values and a monitoring effectivity indicator (cost of one concentration value)

\section{Poděkování}

Autoři děkuji RNDr. Petru Kohoutovi za pořizení fotodokumentace.

\section{Literatura}

[1] Zákon č. 137/2006 Sb., o veřejných zakázkách.

[2] Směrnice Evropského parlamentu a Rady 2000/60/ES ze dne 23. ríjna 2000 ustavující rámec pro činnost Společenství v oblasti vodní politiky.

[3] RIEDER, M., KODEŠ, V., HALÍŘOVÁ, J., HYPR, D. aj. Výskyt a pohyb nebezpečných látek $v$ hydrosfére ČR. Závěrečná zpráva projektu VaV/650/3/00, Praha: ČHMÚ, 2003, 141 s.

[4] KODEŠ, V., KOZÁK, J., KODEŠOVÁ, R., KOČÁREK, M. aj. Výskyt a pohyb pesticidů v hydrosfére a nové metody optimalizace monitoringu pesticidů v hydrosfére ČR. Závěrečná zpráva projektu MŠMT Č. 2B06095, Praha: ČHMÚ, 2011, 82 s.

[5] ČSN EN ISO 5667-1 Jakost vod - Odběr vzorků - Část 1: Návod pro návrh programu odběru vzorků a pro zpưsoby odběru vzorkü. Praha: Český normalizační institut, $32 \mathrm{~s}$.

[6] ČSN EN ISO 5667-11 Kvalita vod - Odběr vzorků - Část 11: Návod pro odběr vzorků podzemních vod. Praha: Český normalizační institut, $32 \mathrm{~s}$. 
[7] ČSN EN ISO 5667-3 Kvalita vod - Odběr vzorků - Část 3: Konzervace vzorků vod a manipulace s nimi. Praha: Český normalizační institut, $56 \mathrm{~s}$.

[8] ČSN EN ISO/IEC 17025 Posuzování shody - Všeobecné požadavky na způsobilost zkušebních a kalibračních laboratoři. Praha: Český normalizační institut, $48 \mathrm{~s}$.

[9] Směrnice Komise 2009/90/ES ze dne 31. července 2009, kterou se podle směrnice Evropského parlamentu a Rady 2000/60/ES stanoví technické specifikace chemické analýzy a monitorování stavu vod.

[10] Vyhláška Ministerstva životního prostředí a Ministerstva zemědělství č. 5/2011 Sb. ze dne 20. prosince 2010 o vymezení hydrogeologických rajonů a útvarů podzemních vod, způsobu hodnocení stavu podzemních vod a náležitostech programů zjištování a hodnocení stavu podzemních vod.

[11] Vyhláška Ministerstva zdravotnictví č. 252/2004 Sb. ze dne 22. dubna 2004, kterou se stanoví hygienické požadavky na pitnou a teplou vodu a četnost a rozsah kontroly pitné vody.

[12] Směrnice Evropského parlamentu a Rady 2006/118/ES ze dne 12. prosince 2006 o ochraně podzemních vod pred znečištěním a zhoršováním stavu.

[13] KODEŠ, V. Výskyt a pohyb nebezpečných látek v podzemních vodách ČR. Acta Hydrologica Slovaca, 4(2), 2003, s. 375-381. ISSN 1335-6291.

[14] Hydrologická ročenka České republiky 2014, Praha: ČHMÚ, 2015, 172 s. ISBN 978-80-87577-57-8.

[15] KODEŠ, V. a SVÁTKOVÁ, M. Výsledky monitoringu pesticidů v podzemních vodách. Sborník príspěvků ze XIV. hydrogeologického kongresu a II. inženýrskogeologického kongresu [online]. Liberec: Technická univerzita v Liberci, 2014, [cit. 28. ledna 2016]. Dostupné z: http://kongres2014.tul.cz/index.php/hig/2014.

[16] Zákon č. 254/2001 Sb., o vodách a změně některých zákonů.

[17] European Environment Information and Observation Network (EIONET) [online]. [cit. 28. ledna 2016]. Dostupné z: https://www.eionet.europa.eu/.

[18] Směrnice Rady 91/676/EHS ze dne 12. prosince 1991 o ochraně vod před znečištěním dusičnany ze zemědělských zdrojů.

[19] Směrnice Evropského parlamentu a Rady 2009/128/ES ze dne 21. řijna 2009, kterou se stanoví rámec pro činnost Společenství za účelem dosažení udržitelného používání pesticidů.

[20] Národní akční plán ke snižení používání pesticidů v České republice [online]. Ministerstvo zemědělství, 2012, [cit. 28. ledna 2016]. Dostupné z: http://eagri.cz/public/web/file/175318/NAP_CZ_schvaleny_vladou.pdf.

\section{Autoři}

Mgr. Vít Kodeš, Ph.D.

凶kodes@chmi.cz

Mgr. Miroslava Svátková

凶svatkova@chmi.cz

Ing. Jindřich Freisleben

凶freisleben@chmi.cz

Český hydrometeorologický ústav, odbor jakosti vody

Příspěvěk prošel lektorským řízením. 